(02016, Elsevier. Licensed under the Creative Commons Attribution-NonCommercialNoDerivatives 4.0 International http://creativecommons.org/about/downloads 


\title{
Federal Reserve's policy, global equity markets, and the local
}

\author{
monetary policy stance.
}

\author{
Georgios Chortareas* and Emmanouil Noikokyris ${ }^{* *}$
}

\begin{abstract}
This paper examines the extent to which local monetary policy stance determines the strength of US monetary policy international transmission to global equities. Using a sample of 35 countries, we document that US monetary policy surprises exert significant inverse effects on global equity returns. Our results suggest that countries whose policy rates are brought into line with that of the US are less sensitive to US monetary policy shocks only when they have a high and intermediate level of cross-border financial linkages, and only when they have a low and intermediate level of exchange rate volatility.
\end{abstract}

Keywords: Equity markets, US monetary policy shocks, international transmission of monetary policy.

JEL Classification: E52, F30, G14, G15.

* Georgios Chortareas, School of Business and Management, King's College London, FranklinWilkins Building, 150 Stamford Str., London SE1 9NH, UK, Email address: georgios.chortareas@kcl.ac.uk

** (Corresponding author) and Emmanouil Noikokyris, Kingston Business School, Kingston University London, Kingston Hill, Kingston upon Thames KT2 7LB, UK, Email address: E.Noikokyris@kingston.ac.uk 


\section{Introduction.}

This paper provides an empirical examination of the international propagation mechanism of US monetary policy shocks to global equity markets. The international dimensions of the Federal Reserve's (Fed) actions have been a topic of continuous scrutiny in the literature, as they carry direct implications for global portfolio allocations, as well as for monetary policymaking. The bulk of research to date has attempted to discern the determinants of global equities' reaction to US monetary policy shocks by conditioning the strength of the transmission, mainly, to the degree of countries' cross-border real and financial integration, and to the flexibility of their exchange rate (e.g., Ammer, Vega, and Wongswan, 2010; Ehrmann and Fratzscher, 2009; Wongswan, 2009). The present study adds to the existing evidence by examining the extent to which local monetary policy stance determines the strength of US monetary policy international transmission.

The present study builds on a long and extensive literature, which, typically, pursues a twofold objective. First, it attempts to establish the existence of international spillover effects, and second, it seeks to identify the determinants of the strength of these effects. Evidence on the nature of the relationship between US monetary policy and international equity returns is rather robust, with the bulk of evidence pointing to a significant inverse relationship between US monetary policy shocks and foreign stock prices. ${ }^{1}$ There is also evidence of a significant link between Federal Open Market Committee (FOMC) communications and international equities (Hayo, Kutan and Neuenkirch, 2010, 2012). Documenting global equities' reaction to US monetary policy shocks and FOMC communications can reveal the extent to which US monetary policy can affect common and country-specific business cycle and asset price fluctuations (Lastrapes, 1998). The motivation for the second objective arises from ongoing

\footnotetext{
1 See Ammer et al., 2010; Bailey, 1990; Conover, Jensen, and Johnson, 1999; Craine and Martin, 2008; Hausman and Wongswan, 2011; Hayo, Kutan and Neuenkirch, 2010, 2012; Hussain, 2011; Johnson and Jensen, 1993; Lastrapes, 1998; Mann, Atra, and Dowen, 2004; Wongswan, 2009.
} 
efforts to uncover the proper course of actions that a country must pursue in order to internalise the externalities associated with US monetary policy (Canova, 2005). To the best of our knowledge, this study is the first to test formally the implications of bringing into line ("synchronising") local policy rates with that of the US for the strength of the US monetary policy transmission to global equities.

The posited channels through which US monetary policy affects foreign firms' cash flows and discount rates can be complex, and the ultimate result on global equity prices is uncertain a priori. For instance, US monetary policy shocks can have significant inverse effects on global equity prices through their impact on the international interest rates, as the latter are used to discount foreign firms' future cash flows. ${ }^{2}$ Simultaneously, however, international interest rate adjustments following innovations to Fed's actions might pass through to exchange rates via uncovered interest rate parity, and also affect foreign firms' cash flows by altering domestic goods' competitiveness. But the impact of these two channels on global equity prices can be offsetting, and their relative importance difficult to predict beforehand (Wongswan, 2009). In a similar vein, innovations to US monetary policy stance can also affect foreign equities because they may trigger global portfolio rebalancing due to changes in the relative returns of global assets (Lastrapes, 1998). Finally, to the extent that the developments in US asset markets and macroeconomic conditions are interrelated with those of global economies, US monetary policy can influence expectations about future returns in global assets through its impact on US economic activity (Lastrapes, 1998).

Intuitively, we expect that countries' sensitivity to externalities associated with US monetary policy is more pronounced when their goods and financial markets are integrated with the rest of world. Furthermore, the nature of a country's exchange rate regime is often

\footnotetext{
${ }^{2}$ The significance of this transmission mechanism is reinforced by evidence indicating that changes in foreign interest rates is a significant amplifier of US monetary policy shocks international transmission (Canova, 2005; Frankel, Schmukler, and Servén, 2004; Kim, 2001).
} 
couched in discussions about the strength of the international financial transmission of US monetary policy, as it determines the extent to which local interest rates adjust to US monetary policy innovations (Frankel et al., 2004; Shambaugh, 2004). Against this background, most of the existing research attempts to operationalise an empirical exploration on this subject by conditioning the differential reactions of global equities to US monetary policy shocks to the differences in cross-border real and financial linkages, as well as to the flexibility of the exchange rate regime.

In this context, a number of recent papers document that countries with a higher degree of real (Ehrmann and Fratzscher, 2009; Hausman and Wongswan, 2011) and financial (Bailey, 1990; Hausman and Wongswan, 2011; Wongswan, 2009) integration with the rest of the world are more sensitive to US monetary policy shocks. Other research focuses on the way foreign interest rates and exchange rates adjust to global interest rate shocks, and finds that equities of countries with flexible exchange rates respond in a less pronounced way to US monetary policy (Ammer et al., 2010; Bailey, 1990; Hausman and Wongswan, 2011). Other factors that can capture the strength of the international financial transmission of US monetary policy include the high degree of equity markets' openness, level of development, riskiness, and the degree of a country's business cycle correlation with the US (Ehrmann and Fratzscher, 2009; Wongswan, 2009).

The feedback responses of local monetary policy to Fed's actions, however, can influence the strength of US monetary policy shocks transmission, and although this possibility has been acknowledged (Ehrmann and Fratzscher, 2009), it has not been formally tested. The reported reaction of global equities, for instance, might not only be due to an unexpected change in US monetary policy, but also due to an adjustment of similar direction to the local monetary policy conditions. In this case, the ultimate impact of Fed's actions on 
international equities would be more pronounced, as foreign stocks will also respond to the changes in local monetary policy conditions.

The synchronisation of policy rates, however, can also reduce the strength of the transmission. A similar policy to that of the US, for instance, can cancel out US monetary policy induced exchange rate adjustments and, given that higher exchange rate volatility amplifies the impact of US monetary policy shocks on global equities (Ehrmann and Fratzscher, 2009), narrow this transmission channel. This posited hypothesis is reinforced by existing evidence which asserts that foreign monetary policymakers use their interest rate policy to cancel out abrupt changes in exchange rates (Calvo and Reinhart, 2002; McCallum, 1994). Moreover, synchronisation of policy rates can also act as a form of signalling for increased monetary policy cooperation reducing equity risk premia and sensitivity to US monetary policy externalities.

The analysis in the present study proceeds in three steps. First, in subsection 2.1 we explore the relationship between US monetary policy shocks and global equities. Using an event-study framework, consistent with the bulk of existing recent literature (Ammer et al., 2010; Ehrmann and Fratzscher, 2009; Hausman and Wongswan, 2011; Wongswan, 2009), we capture the immediate effects of US monetary policy shocks on the daily stock returns of 35 countries.

Second, in subsection 2.2 we characterise the degree of monetary policy interdependence between the US and the countries in our sample, and we seek to identify the extent to which the strength of international equities' reaction to US monetary policy shocks hinges on the level of a country's monetary policy interdependence with that of the US. Although monetary policy coordination can materialise in different forms, in this study we consider the synchronisation of interest rate policies, similarly to Bergin and Jordà (2004) and 
Shambaugh (2004). We consider two different definitions for the commonality of monetary policy conditions between the US and a foreign country in this study. The first is a timevarying definition of commonality, based on the monthly indicators for countries' monetary policy conditions (see Conover et al., 1999; Mann et al., 2004). We identify those countries which for a certain period share similar monetary policy conditions with the US. The second approach follows the technique developed by Bergin and Jordà (2004), and allows to identify those countries whose policy rate changes are more likely to move in the same direction with the Fed's policy rate.

The third step, in subsection 2.3, consists in investigating how country-specific characteristics influence the strength of the international financial transmission of US monetary policy to the countries synchronising their policy rates with that of the US. In this context, we categorise countries according to the degree of their cross-border real and financial linkages as well to the flexibility of their exchange rates, and we analyse the differences. Finally, section 3 offers some concluding remarks.

\section{The response of global equities to US monetary policy shocks.}

\subsection{Baseline event-study results.}

We seek to identify the effects of US monetary policy shocks on global equity markets using a pooled regression-based event study approach. The event-study approach has been used extensively in the stream of research which seeks to identify the effects that FOMC announcements elicit on international stock market returns (see inter alia Ammer et al., 2010; Ehrmann and Fratzscher, 2009). This approach provides the empirical framework for 
identifying the average effects of FOMC announcement surprises on foreign stock returns. Moreover, it provides flexibility for capturing the differential response of global equities to US monetary policy shocks across different subsets of a given sample.

The starting point of our analysis is the estimation of the following equation using panel data:

$$
r_{j, i}=c+\beta_{1} S_{i}+\varepsilon_{j, i}
$$

where $r_{j, i}$ is the daily $(\log )$ returns of country's $j$ aggregate stock market price index on an FOMC meeting day $i$, and $S_{i}$ stands for the unexpected component of the monetary policy announcements calculated in a similar manner to Kuttner (2001). In a similar vein to the existing literature, we obtain ordinary least squares estimates for the average reaction of foreign stock market returns to monetary policy shocks. In addition to this we use the method of Petersen (2009) to calculate panel-corrected standard errors which are robust to two dimensions of within-cluster correlation.

Our analysis covers 35 countries comprising of 30 OECD and 5 key partners to the OECD countries. In particular, we consider the following countries: Australia, Austria, Belgium, Brazil, Canada, Chile, China, Czech Republic, Denmark, Finland, France, Germany, Greece, Hungary, India, Indonesia, Ireland, Israel, Italy, Japan, Luxembourg, Mexico, Netherlands, New Zealand, Norway, Poland, Portugal, Republic of Korea, Slovenia, South Africa, Spain, Sweden, Switzerland, Turkey, and the United Kingdom. We obtain aggregate stock market returns from the Datastream calculated price indices, expressed in national currencies, similarly to Ehrmann and Fratzscher (2009).

Our sample, which extends from February 1994 to September 2008, allows considering 118 scheduled FOMC announcements. On scheduled meeting days, most of the monetary 
policy announcements take place at around 14.15 $\mathrm{EST}^{3}$, when the stock markets in Europe and Asia are closed. For these countries, therefore, we consider the following trading day's stock returns in order to estimate the contemporaneous effects of FOMC announcements' monetary policy shocks. We restrict our analysis to include FOMC announcements up to the end of 2008, when the Fed set the range of its target rate between 0 and 0.25 , and started operating at the zero lower bound adopting unconventional monetary policy practices.

-Table 1 here-

The results from the estimation of Eq. (1) are reported in Table 1. The positive and statistically significant estimate for the intercept suggests that global equities' returns average value is positive on the 118 announcement days. Higher average returns on FOMC announcement days possibly reflect the higher equity premium demanded by investors in anticipation of scheduled monetary policy announcements (Savor and Wilson, 2013). Similar findings have been reported in previous related studies (e.g., Kurov, 2012; Wongswan, 2009). The results from the estimation of Eq. (1) also reveal a negative relationship between US monetary policy shocks and international stock market returns. Specifically, we find that a 25 basis points surprise tightening (easing) in the US monetary policy rate will decrease (increase) foreign stock market prices by about $0.8 \%$. This result is consistent with the findings of previous studies that employ similar event-study techniques to examine the impact of unexpected FOMC actions on daily returns of international aggregate stock market indices (Ehrmann and Fratzscher, 2009; Hausman and Wongswan, 2011). When, however, the intra-day response of global equities to US monetary policy shocks is considered, the international financial transmission of US monetary policy appears to be more pronounced

\footnotetext{
3 There are two occasions when the scheduled announcement of the FOMC action took place before noon (Lucca and Moench, 2015). These two cases refer to the FOMC meeting on February $4^{\text {th }} 1994$, when the announcement took place at 11:05, and the FOMC meeting on March $26^{\text {th }} 1996$, when the announcement took place at 11:39.
} 
(Ammer et al., 2010; Wongswan, 2009). We also include in Eq. (1) a term capturing the anticipated component of US monetary policy announcements, calculated as the difference between the actual change in the Fed's rate and the unanticipated one (Kuttner, 2001). Our results, reported in Table 1, remain unaffected.

Although the stronger reaction of international equities in the first minutes of a US monetary policy announcement might be due to a market overreaction, inaccurate results might also emerge when daily stock returns are employed to gauge the US monetary policy shocks effects on global equities (Thornton, 2013). Specifically, the accurate identification of the international transmission might be thwarted, because other news, unrelated to US monetary policy, occurring on the same day, both domestic and imported, might also affect asset prices. To control, therefore, for the robustness of our results from the estimation of $E q$. (1), we employ Thornton's (2013) approach which controls for the possibility that the stock prices and the market-based proxies for monetary policy shocks respond simultaneously to news unrelated to US monetary policy without using intra-day data.

This approach involves the estimation of the following equation:

$$
r_{j, t}=c+\beta_{1} S_{t}+\beta_{2} S_{t} \mathrm{X}_{t}^{A N N}+\beta_{3} \mathrm{X}_{t}^{A N N}+\varepsilon_{j, t}
$$

where $X^{A N N}$ is a dummy variable taking the value of 1 on days of FOMC announcements and zero otherwise, while $t$ refers to all days in our sample and not just to the FOMC announcements days. The results from the estimation of Eq. (2) are reported in Table 1, and are also indicative of a significant US monetary policy international transmission channel. The coefficient estimate $\beta_{2}$, capturing international equities' additional response to US monetary policy shocks on days of FOMC announcements, is statistically significant and negative. Moreover, coefficient estimate $\beta_{1}$ which measures the simultaneous response of 
global equities and market-based measures for US monetary policy shocks is statistically insignificant.

The benchmark specification of the event-study excludes monetary policy actions taken on unscheduled FOMC meetings. This is because the last tend to be associated with specific circumstances requiring an urgent response from the Fed (Bernanke and Kuttner, 2005). Consider for instance, the rate cut on September $17^{\text {th }} 2001$, which came as a response to the 9/11 terrorist attacks, and the rate cut on January $22^{\text {nd }} 2008$ (the largest in 20 years) in response to the deepening of the financial crisis. Such actions reflect Fed's responses to extraordinary situations, and they are usually classified as 'outlier events' in related studies, increasing the size of equities' response (see for e.g., Bernanke and Kuttner, 2005; Kontonikas, MacDonald \& Saggu, 2013).

Nevertheless, it would be interesting to examine if global equities respond in a different manner to monetary policy shocks emanating from unscheduled FOMC announcements. During the period from February 1994 until September 2008, 118 scheduled FOMC meetings and 6 unscheduled meetings occurred, excluding that on September $17^{\text {th }} 2001$. We estimate, therefore, the following equation:

$$
r_{j, i}=c+\beta_{1} S_{i}+\beta_{2} S_{i} X_{i}^{U N}+\varepsilon_{j, i}
$$

where $X^{U N}$ is a $0-1$ dummy variable taking the value of 1 on unscheduled FOMC meeting days and $i$ now includes both scheduled and unscheduled FOMC meeting days. The results from this regression (reported in Table 1) do not show a statistically significant marginal reaction of global equities to monetary policy shocks originating from unscheduled FOMC meetings. 
The event-study framework adopted in this paper is based on the implicit assumption that monetary policy news is the only factor driving equity prices on FOMC announcement days. Similar daily or intra-day event-windows have also been employed in previous related studies (Ammer et al., 2010; Ehrmann and Fratzscher, 2009; Hausman and Wongswan, 2011; Wongswan, 2009). The observed daily equity performance, however, might be due to a prolonged episode of increasing or decreasing equity prices in a country, which is unrelated to US monetary policy developments. ${ }^{4}$

Thus, to address this possibility and its implications we also consider the relationship between US monetary policy shocks and global equities' 'abnormal' returns. Specifically, we adjust the daily equity returns of each country in our event study by subtracting the mean of their past performance over 3- and 5-days directly preceding the announcement day, and explore their association with US monetary policy surprises. The regression of global equities' abnormal returns on monetary policy surprises yields statistically insignificant reaction estimates, as we show in Table 1 , and challenges existing evidence of a strong passthrough of US monetary policy into global equities. We use this measure of equity performance in the remaining part of the paper to test if this average result holds for all subsets of the sample we are examining in this paper.

\subsection{The role of domestic monetary policy conditions.}

In this section, we seek to identify the extent to which monetary conditions in the non-US countries determine the cross-border differences in the impact of US monetary policy on global equities. We examine whether the commonality, or not, of the monetary policy conditions in the 35 countries from our sample with those of the US influence the strength of US monetary policy international pass-through into international stock markets. An important

\footnotetext{
${ }^{4}$ We thank an anonymous referee for suggesting this line of analysis.
} 
aspect of our analysis in this section is, therefore, the uncovering of the degree of a country's monetary policy interdependence with that of the US.

First, in order to identify the degree of monetary policy interdependence between two countries we use the monthly indicators for countries' monetary policy environments employed in Jensen and Johnson (1995), Jensen et al. (1996), Conover et al. (1999), and Mann et al. (2004). Using this classification, the monetary policy environment of a country can be classified as either tightening or easing based on the most recent change in the policy rate. Specifically, a country's monetary policy environment is characterised as restrictive after an increase in the policy rate, while the easing monetary phase starts after a policy rate cut. The assumption on which this binary classification of a country's monetary policy conditions rests is that monetary policy conditions remain unchanged until there is a reverse in the policy rate. In the present study, we relax this assumption, and we also consider a monetary policy inaction phase which starts on a month when a country has left its policy rate unchanged 12 consecutive times. The monetary policy environments of two countries are common when they share similar monetary policy conditions. In Table A.1 in the Appendix, we provide information about the policy rates used for each country, as well as for their availability. This approach has the advantage of allowing for a time-varying definition of commonality between the monetary policy of a country and that of the US. ${ }^{5}$

The second approach we use in order to determine the degree of monetary policy interdependence between the US and each one of the countries from our sample is based on Bergin and Jordà's (2004) directional model. Using an ordered probit model, this method seeks to identify whether US monetary policy rate changes affect the likelihood of changes in

\footnotetext{
${ }^{5}$ In order to construct the monetary policy synchronisation dummy variable, we also use the original binary specification of a country's monetary policy stance which does not consider the monetary policy inaction period (e.g., Conover et al., 1999 and Mann et al., 2004). We repeat the estimations in Tables 3 and 4, and our results are qualitatively similar. For brevity reasons we do not present these results, but they are available from the authors upon request.
} 
similar direction in the policy rates of other countries. The model of Bergin and Jordà (2004), however, examines only whether changes in the target countries' monetary policy rates are due to US monetary policy, and does not consider periods when the target countries' policy rates have not changed. This specification of the ordered probit model involves estimations in event time (the event is the change in the policy rate of the target country), rather than time series estimations, excluding consequently all those months when a target country did not adjust its policy rate.

In order to consider periods of monetary policy inactivity, we depart from the original specification of Bergin and Jordà (2004), and we consider ordered probit estimations in a time series setting including all months from February 1994 to September 2008. Based on the assumption that central banks adjust their policy rates in discrete increments, we categorise each policy rate adjustment of a central bank $(\Delta r)$ in five broad categories: strong decrease $\left(k_{1}\right)$, decrease $\left(k_{2}\right)$, inactivity $\left(k_{3}\right)$, increase $\left(k_{4}\right)$, and strong increase $\left(k_{5}\right)$. Thus, we include an additional category to capture the months when no policy rate changes have taken place. Conditional to the variability of the policy rate changes in each country during the period under consideration, we classify the policy rate changes into these five categories. In particular, for each country we use the classification system shown in Table A.1 of the appendix. For instance, the values that a US monetary policy rate adjustment can take are $k_{l}=$ $-0.5 \%, k_{2}=-0.25 \%, k_{3}=0 \%, k_{4}=0.25 \%$, and $k_{5}=0.5 \%$, while those of Mexico are $k_{1}=-$ $0.75 \%, k_{2}=-0.25 \%, k_{3}=0 \%, k_{4}=0.25 \%$, and $k_{5}=0.75 \%$.

Based on this classification, we can have for each country 5 different occurrences in every month $t$. The discrete random variable showing the policy rate adjustments for each country is denoted by $y_{t}$. The ordered response model proposed by Bergin and Jordà (2004) takes the following form: 


$$
\begin{aligned}
& P\left(y_{t}=k_{m} \mid \Omega_{t-1}\right)=P\left(c_{m-1}<y_{t}^{*}<c_{m} \mid \Omega_{t-1}\right), \\
& y_{t}^{*}=\beta^{\prime} w_{t}+\varepsilon_{t}
\end{aligned}
$$

where $\varepsilon_{t} \sim \mathrm{N}(0,1), y_{t}^{*}$ is a latent continuous variable, and the threshold parameters of this ordered choice model $\mathrm{c}_{m}, m=0,1,2,3,4,5$ are such that $-\infty=c_{0}<c_{1}<c_{2}<c_{3}<c_{4}<c_{5}=+\infty$. The vector of explanatory variables $w_{t}$ includes the following: the next year's expected inflation rate minus 2\% (Consensus Economics), the next year's expected gross domestic product growth minus $2.5 \%$ (Consensus Economics), the monthly percentage change in a country's effective exchange rate (BIS Nominal Broad Indices), and the discrete random variable $y_{t}^{U S}$ capturing US monetary policy rate adjustments. All variables in vector $w_{t}$ are of monthly frequency, and are included in Eq. (4) in lagged form to capture the information set available in the month just before the $t^{\text {th }}$ month $\left(\Omega_{t-1}\right)$. Contrary to the original specification of Bergin and Jordà (2004), we use forward-looking data for inflation and real economic activity in our estimations of the ordered probit model, as they reflect more accurately the forward-looking nature of monetary policy.

-Table 2 here-

We estimate $E q$. (4) for each one of the 35 countries in our sample, and we report the results in Table 2. For countries participating in the Eurozone, we estimate Eq. (4) separately for each country's policy rate for the period before January 1999. After the introduction of the euro in January 1999, we consider the relationship between US monetary policy rate and the policy rate set by the European Central Bank. Our results show that for 14 out of 35 countries, as well as all for the Euro area after January 1999 the reaction estimate of $y_{t}$ to the discrete US monetary policy rate adjustments $y_{t}^{U S}$ is positive and statistically significant. That is, the central banks under consideration are more likely to adjust their policy rates in the 
same direction as the US policy rate, and, thus, these countries are more likely to have similar monetary policy conditions with the US. ${ }^{6}$

To get a better sense of the magnitude of the impact of US monetary policy on the probability of each occurrence of $y_{t}$, we show, in Table A.2 in the appendix, the marginal effects of $y_{t}^{U S}$ for those countries which we find from the estimations of Eq. (4) to be more likely to adjust their policy rates in the same direction as the Fed. The signs of the marginal effects are consistent with those obtained from the coefficient estimates, as a unit increase (25 basis points of the US monetary policy rate) in $y_{t}^{U S}$ decreases the possibility of "strong decreases" and "decreases" in foreign policy rates, while it increases the possibility of "increases" and "strong increases". US monetary policy rate adjustments increase and/or decrease the probability of most outcomes of the discrete random variable $y_{t}$, but they appear to generate a larger impact on the outcomes of "increases" and "decreases". The only exceptions are Slovenia and the Republic of Korea where we find that they are associated only with "strong decreases" and "increases" respectively. ${ }^{7}$

The equation by which we assess how the synchronisation of local monetary policy rates with that of the US impacts on the strength of the baseline relationship in Eq. (1), is

$$
r_{j, i}=c+\beta_{1} S_{i}+\beta_{2} S_{i} X_{j, i}^{S Y N}+\varepsilon_{j, i}
$$

where $X^{S Y N}$ is a binary dummy variable taking the value of 1 if country $j$ at time $i$ has the same monetary conditions with the US, and zero otherwise. Based on the analysis above, the policy rates synchronisation dummy variable $X^{S Y N}$ can take two definitions. First, we use the

\footnotetext{
${ }^{6}$ We thank an anonymous referee for the suggestion to include the months when policy rates were left unchanged and for suggesting the use of forward-looking data in $w_{t}$.

${ }^{7}$ We have also employed the original specification of Bergin and Jordà (2004) in order to identify the countries which are more likely to adjust their monetary policy rates in a similar direction to that in the US. This exercise is conducted in event time and the explanatory variables in vector $w_{t}$ are backward looking. When we repeat the estimations in Tables 3 and 4 using these countries our results are qualitatively similar. For brevity reasons these results are not included here, but are available from the authors upon request.
} 
time-varying definition of commonality and $X^{S Y N}$ takes the value 1 on event days $i$ when the monetary policy conditions in country $j$, defined using an adaptation of the method of Conover et al. (1999) and Mann et al. (2004), are similar to those in the US, and zero otherwise. Second, it takes the value of 1 for those countries whose policy rates are more likely to respond in the same direction as the Fed's policy rate that we have identified using the directional model of Bergin and Jordà (2004) described above.

-Table 3 here-

Table 3 reports results from the estimation of Eq. (5), and show that on average, and irrespective of which monetary policy synchronisation definition we use, when foreign countries' monetary policy rates are in synch with the US policy rate, the impact of US monetary policy shocks on global equity markets tends to be on average less pronounced. Specifically, the coefficient estimates $\beta_{2}$ capturing the marginal response of equities in countries whose monetary policy rate moves in tandem with that of the US is positive and statistically significant. In addition, after the interactive term of surprises with the monetary policy synchronisation dummy is included, the magnitude of the international equities' reaction estimate $\beta_{1}$ increases.

In Table 3 we also show the results from Eq. (5) when abnormal returns are employed, and our results are comparable to those obtained when the reaction of daily returns is sought. In this section, therefore, we show that there is a significant negative relationship between global equities returns (and abnormal returns) and US monetary policy shocks on FOMC announcement days, unless foreign monetary policy rates are in synch with the US monetary policy rate. In that case the impact is less pronounced or even completely diminished as the results from testing if the sum of coefficients $\beta_{1}$ and $\beta_{2}$ is zero, reported in Table 3, depict.

\subsection{The role of other forms of interaction among countries}


In the previous section, we have shown that the synchronisation of domestic monetary policy rates with that of the US reduces on average, and even diminishes, the strength of the international transmission of US monetary policy shocks to global equities. In the subsequent part, we proceed to investigate if this result is robust across all countries sharing similar monetary policy conditions with the US. In particular, we investigate if other forms of interaction between a country and the rest of the world can explain why the strength of the transmission channel is reduced in countries with similar monetary policy conditions to those in the US. The factors we consider are the cross-border real and financial linkages of a country, as well as the flexibility of its exchange rate.

To uncover if the muted reaction of global stocks to Fed's unexpected actions can be pinned down to specific countries which share some similar characteristics along with synchronised policy rates with the US, we augment $E q$. (5) by adding 3 interactive terms as follows:

$$
r_{j, i}=c+\beta_{1} S_{i}+\beta_{2} S_{i} X_{j, i}^{S Y N} X_{j, i}^{L O W}+\beta_{3} S_{i} X_{j, i}^{S Y N} X_{j, i}^{M E D}+\beta_{4} S_{i} X_{j, i}^{S Y N} X_{j, i}^{H I G H}+\varepsilon_{j, i}
$$

$X^{L O W}, X^{M E D}, X^{H I G H}$ are 0-1 dummy variables, which have been developed in the spirit of Ehrmann and Fratzscher (2009). Each one picks up the marginal reaction of the equities of the one third of the countries from our sample which at event time $i$ they have the lowest, medium and highest values of the proxy for cross-border real and financial linkages and for the exchange rate flexibility, respectively. Detailed information regarding the way the dummy variables have been developed can be found in Table A. 3 in the appendix.

To start with, we examine if the less pronounced impact under monetary policy synchronisation hinges on the degree of a country's real economic integration with the world. The total amount of a country's trade (exports plus imports) as well as the total exports to the US as a percentage to its GDP are the two measures employed to proxy for the degree of a 
country's real economic linkage with the rest of the world and the US. Coefficient estimate $\beta_{2}$ reflects the marginal reaction of equities in countries which have synchronised their monetary policy rate with the US target rate, but also with a lower degree of real integration with the rest of the world. Coefficient estimate $\beta_{4}$ shows the marginal reaction of equities in countries both having synchronised policy rates with the US and high cross-border real linkages with the rest of the world. Coefficient estimate $\beta_{3}$, finally, shows the partial reaction of equities in counties with synchronised policy rates with the US and an intermediate degree of real economic integration.

-Table 4-

Table 4 reports results from the estimation of Eq. (6). The choice of the synchronisation dummy appears to influence our results to some extent. When the time-varying definition of monetary policy rates synchronisation is employed (see panel A of Table 4), the positive marginal impact of the monetary policy synchronisation dummy is identifiable to countries captured under the $X^{H I G H}$ and $X^{M E D}$ categories. On the contrary, when the directional model of Bergin and Jordà's (2004) is employed to identify countries whose policy rates are in synch with that of the US (see panel B of Table 4), the on average reduced responsiveness of foreign stocks to US monetary policy shocks is also seen for countries with low exports to the US. The role of the degree of a country's real economic integration with the rest of the world in the strength of the results from $E q .(5)$ is therefore, unclear.

In part (b) of Table 4, we report the results from the estimation of Eq. (6) only that now dummy variables $X^{L O W}, X^{M E D}$ and $X^{H I G H}$ categorise countries according to their degree of financial integration with the world and the US at event day $i$. Specifically, we condition the magnitude of the policy rates synchronisation dummy to the amount of global financial assets that a country is exposed to. Following Ehrmann and Fratzscher (2009) we focus on asset and 
liability holdings of the banking sector, on foreign direct investments and on portfolio investments (equity and debt instruments). Moreover, we consider the amount of a country's US equity holdings as a percentage of their domestic stock market capitalisation. Although most of these indicators are highly correlated, and, therefore, they should not be expected to produce different results, it is typical in this literature to employ several indicators for crossborder real and financial linkages for reasons of robustness (e.g., Ehrmann and Fratzscher, 2009; Hausman and Wongswan, 2011; Wongswan, 2009).

Although there are some differences in the results based on which policy rates synchronisation dummy variable we employ, a common pattern emerges. Monetary policy rates synchronisation dampens US monetary policy pass-through into global equity markets only for countries with at least an intermediate level of financial integration with the rest of the world and the US. When the time-varying definition of monetary policy rates synchronisation is employed (see panel A of Table 4), only the estimates for countries which at event time $i$ have an intermediate $\left(\beta_{3}\right)$ and high level $\left(\beta_{4}\right)$ of financial integration with the rest of the world (and the US) appear to be statistically significant. For the countries in our sample whose policy rates are more likely to respond in the same direction to Fed's policy rate changes (see panel $\mathrm{B}$ of Table 4), we find similar results only that now the amount of a country's lending to the US and of equity portfolio investments to the US do not seem to be relevant factors influencing our results from the estimation of Eq. (5).

Finally in part (c) of Table 4, we report the results from the estimation of Eq. (6) where we control for the degree of a country's exchange rate flexibility. This study uses two proxies for the exchange rate flexibility, one based on the de facto classification of Ilzetzki, Reinhart, and Rogoff (2010), and the other one on the actual exchange rate volatility. Based on our results for both monetary policy rates synchronisation dummies, the country's de facto 
exchange rate regime does not appear to be a significant factor driving our results from the estimation of Eq. (5). As for the actual exchange rate volatility, we find that muted reactions under policy rates synchronisation coincide with intermediate levels of exchange rate volatility. Based on this result, countries with very volatile exchange rates cannot internalise the externality of US monetary policy shocks simply by synchronising their policy rates with the US. We also repeat the estimations of Eq. (6) in Table 4 using abnormal returns instead of daily $(\log )$ returns, but this does not change our main results. ${ }^{8}$

\section{Conclusion}

This paper attempts to identify empirically the extent to which local monetary policy conditions tend to influence the magnitude of the US monetary policy propagation to global equity markets. Although previous related studies hinted to this question (Ehrmann and Fratzscher, 2009), to the best of our knowledge, it has not been formally tested yet. The main finding of this paper is that local monetary policy conditions are an important factor driving the strength of the US monetary policy transmission to global equities. In particular, we find that the strength of the transmission appears to be less pronounced, and even disappears, if a country's policy rates are synchronised with that of the US.

The empirical analysis is pursued in the context of an event-study framework using a sample of 35 OECD countries and key partners of them. The empirical evidence we produce cover the period 1994-2008, during which took place 118 scheduled FOMC announcements. A central aspect of the analysis of this paper is the uncovering of the degree of a country's monetary policy interdependence with that of the US, and we have used two techniques to address this issue. First, based on the monthly indicators of a country's monetary policy

\footnotetext{
${ }^{8}$ The results are available from the authors upon request.
} 
stance developed by Conover et al. (1999) and Mann et al. (2004), we find those countries which share similar monetary policy conditions with the US at each event time. Second, based on the ordered response model of Bergin and Jordà (2004), we find those countries which are more likely to adjust their policy rates in a similar direction to the Fed. Our results suggest that equity markets of countries sharing similar monetary policy conditions with the US are less sensitive to US monetary policy shocks.

Furthermore, we measure the extent to which the results about the moderated impact under monetary policy synchronisation are conditional to countries' degree of cross-border linkages in goods and financial markets as well as to the flexibility of their exchange rates. We find that monetary policy rates synchronisation does not reduce equities' reaction to US monetary policy shocks in countries segmented from global financial markets or with very volatile exchange rates.

The findings of this paper underscore the significance of non-US monetary policy in the strength of the transmission of US monetary policy to global equities. Based on the empirical evidence presented in this paper, it is hard to tell why the synchronisation of monetary policy rates with that of the US reduces the overall strength of the transmission. The findings of this paper, however, may be useful in further studies as a means for understanding the determinants of the strength of the international propagation mechanism of US monetary policy. Furthermore, our findings may have policymaking implications, as they cast some light in the ways a country can use its monetary policy rate to internalise the externalities associated with US monetary policy shocks. 


\section{REFERENCES}

Ammer, J., Vega, C., \& Wongswan, J. (2010). International transmission of U.S. monetary policy shocks: Evidence from stock prices. Journal of Money, Credit and Banking, 42, 179-198.

Bailey, W. (1990). US money supply announcements and pacific rim stock markets: Evidence and implications. Journal of International Money and Finance, 9(3), 344-356.

Bergin, P. R., \& Jordà, Ò. (2004). Measuring monetary policy interdependence. Journal of International Money and Finance, 23(5), 761-783.

Bernanke, B. S., \& Kuttner, N. K. (2005). What explains the stock market's reaction to Federal Reserve policy? The Journal of Finance, 60(3), 1221-1257.

Calvo, G. A., \& Reinhart, C. M. (2002). Fear of floating. The Quarterly Journal of Economics, 117(2), 379-408.

Canova, F. (2005). The transmission of US shocks to Latin America. Journal of Applied Econometrics, 20(2), 229-251.

Conover, C. M., Jensen, G. R., \& Johnson, R. R. (1999). Monetary environments and international stock returns. Journal of Banking \& Finance, 23(9), 1357-1381.

Craine, R., \& Martin, V. L. (2008). International monetary policy surprise spillovers. Journal of International Economics, 75(1), 180-196.

Ehrmann, M., \& Fratzscher, M. (2009). Global financial transmission of monetary policy shocks. Oxford Bulletin of Economics and Statistics, 71(6), 739-759.

Frankel, J., Schmukler, S. L., \& Servén, L. (2004). Global transmission of interest rates: Monetary independence and currency regime. Journal of International Money and Finance, 23(5), 701-733.

Hausman, J., \& Wongswan, J. (2011). Global asset prices and FOMC announcements. Journal of International Money and Finance, 30(3), 547-571. 
Hayo, B., Kutan, A., \& Neuenkirch, M. (2010). The Impact of U.S. Central Bank Communication on European and Pacific Equity Markets. Economics Letters 108 (2), $172-174$.

Hayo, B., Kutan, A., and Neuenkirch, M. (2012). Federal Reserve Communications and Emerging Equity Markets. Southern Economic Journal 78 (3), 1041-1056.

Hussain, S. M. (2011). Simultaneous monetary policy announcements and international stock markets response: An intraday analysis. Journal of Banking \& Finance, 35(3), 752-764.

Ilzetzki, E., Reinhart C.M., Rogoff, K.S., 2010. Exchange rate arrangements entering the 21st century: Which anchor will hold? Mimeo. University of Maryland and Harvard University.

Jensen, G. R. \& Johnson, R. R. (1995). Discount rate changes and security returns in the U.S., 1962-1991. Journal of Banking and Finance, 19(1), 79-95.

Jensen, G. R. Mercer, J.M. \& Johnson, R. R. (1996). Business conditions, monetary policy, and expected security returns. Journal of Financial Economics, 40(2), 213-237.

Johnson, R. R., \& Jensen, G. R. (1993). The reaction of foreign stock markets to U.S. discount rate changes. International Review of Economics \& Finance, 2(2), 181-193.

Kim, S. (2001). International transmission of U.S. monetary policy shocks: Evidence from VAR's. Journal of Monetary Economics, 48(2), 339-372.

Kontonikas, A., MacDonald, R. \& Saggu, A. (2013). Stock market reaction to fed funds rate surprises: State dependence and the financial crisis. Journal of Banking and Finance, $37(11), 4025-4037$.

Kurov, A. (2012). What determines the stock market's reaction to monetary policy statements? Review of Financial Economics, 21(4), 175-187.

Kuttner, K. N. (2001). Monetary policy surprises and interest rates: Evidence from the fed funds futures market. Journal of Monetary Economics, 47(3), 523-544. 
Lastrapes, W. D. (1998). International evidence on equity prices, interest rates and money. Journal of International Money and Finance, 17(3), 377-406.

Lucca, D.O., \& Moench, E. (2015). The Pre-FOMC Announcement Drift. Journal of Finance 70(1), 329-371.

Mann, T., Atra, R. J., \& Dowen, R. (2004). U.S. monetary policy indicators and international stock returns: 1970-2001. International Review of Financial Analysis, 13(4), 543-558.

McCallum, B. T. (1994). A reconsideration of the uncovered interest parity relationship. Journal of Monetary Economics, 33(1), 105-132.

Petersen, M. A. (2009). Estimating standard errors in finance panel data sets: Comparing approaches. Review of Financial Studies, 22(1), 435-480.

Shambaugh, J. C. (2004). The effect of fixed exchange rates on monetary policy. The Quarterly Journal of Economics, 119(1), 301-352.

Savor, P. \& Wilson, M. (2013). How much do investors care about macroeconomic risk? Evidence from scheduled economic announcements. Journal of Financial and Quantitative Analysis, 48(2), 343-375.

Thornton, D. L. (2013). The identification of the response of interest rates to monetary policy actions using market-based measures of monetary policy shocks. Oxford Economic Papers, 66(1), 67-87.

Wongswan, J. (2009). The response of global equity indexes to U.S. monetary policy announcements. Journal of International Money and Finance, 28(2), 344-365. 


\section{TABLES}

\section{TABLE 1}

GLOBAL EQUITY RETURNS AND US MONETARY POLICY SURPRISES

\begin{tabular}{|c|c|c|c|c|c|c|c|c|}
\hline & $c$ & $S_{i}$ & $E_{i}$ & $X_{t}^{A N N}$ & $S_{t} \times X_{t}^{A N N}$ & $S_{i} \times X_{i}^{U N}$ & $R^{2}(\%)$ & Obs. \\
\hline$r_{j, i}$ & $\begin{array}{c}0.19 * * * \\
(3.09)\end{array}$ & $\begin{array}{l}-3.11 * * \\
-2.08)\end{array}$ & - & - & - & - & 1.42 & 4,086 \\
\hline$r_{j, i}$ & $\begin{array}{c}0.19 * * * \\
(2.93)\end{array}$ & $\begin{array}{l}-3.19 * * \\
(-2.08)\end{array}$ & $\begin{array}{c}0.44 \\
(1.48)\end{array}$ & & & & 1.94 & 4,086 \\
\hline$r_{j, i}$ & $\begin{array}{c}0.02 * * \\
(2.08)\end{array}$ & $\begin{array}{c}0.55 \\
(1.24)\end{array}$ & - & $\begin{array}{c}0.17 * * * \\
(2.63)\end{array}$ & $\begin{array}{c}-3.67 * * \\
(-2.36)\end{array}$ & - & 0.12 & 133,170 \\
\hline$r_{j, i}$ & $\begin{array}{c}0.23 * * * \\
(3.61)\end{array}$ & $\begin{array}{l}-3.07 * * \\
(-2.05)\end{array}$ & - & 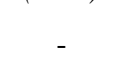 & - & $\begin{array}{c}1.58 \\
(0.77)\end{array}$ & 1.85 & 4,363 \\
\hline$r_{j, i}^{3-\text { days }}$ & $\begin{array}{l}0.16 * * \\
(2.30)\end{array}$ & $\begin{array}{l}-2.06 \\
(-1.14)\end{array}$ & - & - & - & - & 0.50 & 4,086 \\
\hline$r_{j, i}^{5-d a y s}$ & $\begin{array}{l}0.18 * * \\
(2.52)\end{array}$ & $\begin{array}{l}-2.28 \\
(-1.30)\end{array}$ & - & - & - & - & 0.63 & 4,086 \\
\hline
\end{tabular}

of 35 global equity price indices on the market-based proxy for US monetary policy shocks $(S)$ on the 118 event days described in the main body of the text. In the second row we also include in $E q$. (1) variable $E_{i}$ which stands for the anticipated component of a US monetary policy announcement. In the third row of this table, we show results from the estimation of $E q$. (2), which now includes in the pooled regression all days from January $3^{\text {rd }} 1994$ to September $30^{\text {th }} 2008$, and $X^{A N N}$ is a $0-1$ dummy variable taking the value of 1 on FOMC announcement days, and zero otherwise. The fourth row of this table shows the results from the estimation of Eq.(3), which now includes both scheduled and unscheduled FOMC meetings announcements, and $X^{U N}$ is $0-1$ dummy variable taking the value of 1 on unscheduled FOMC meetings announcements, and zero otherwise. In the fifth and sixth rows of this table we show the results from the estimation of Eq. (1), where $r^{3-d a y s}$ and $r^{5 \text {-days }}$ are the daily equity returns of each country on the 118 announcement days adjusted by subtracting the mean of their past performance over 3- and 5-days directly preceding the announcement day, respectively. Coefficient estimates are obtained by the OLS method, and t-statistics (.) are calculated using the two-dimensional clustered standard errors of Petersen (2009).

$* / * * / * * *$ denote significance at $90 \%, 95 \%$, and $99 \%$ confidence levels respectively. 
TABLE 2

MONETARY POLICY INTERDEPENDENCE WITH THE US

\begin{tabular}{|c|c|c|c|c|c|c|c|}
\hline Country & Inflation & Growth & Eff. XR & US MP & Log.Lik. & 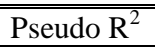 & Obs. \\
\hline Australia & $\begin{array}{c}0.51 * * * \\
(0.19)\end{array}$ & $\begin{array}{c}0.44 \\
(0.28)\end{array}$ & $\begin{array}{c}0.15 * * * \\
(0.05)\end{array}$ & $\begin{array}{l}1.11 * * \\
(0.54)\end{array}$ & -114.17 & 9.27 & 175 \\
\hline Austria & $\begin{array}{c}-5.02 * * * \\
(1.45)\end{array}$ & $\begin{array}{l}3.24 * * \\
(1.29)\end{array}$ & $\begin{array}{c}0.15 \\
(0.36)\end{array}$ & $\begin{array}{l}-0.21 \\
(1.34)\end{array}$ & -15.42 & 47.85 & 58 \\
\hline Belgium & $\begin{array}{c}-2.10^{* * *} \\
(0.82)\end{array}$ & $\begin{array}{c}0.57 \\
(0.76)\end{array}$ & $\begin{array}{c}0.22 \\
(0.28)\end{array}$ & $\begin{array}{c}0.23 \\
(1.33)\end{array}$ & -26.42 & 16.36 & 58 \\
\hline Brazil & $\begin{array}{c}0.06 \\
(0.05)\end{array}$ & $\begin{array}{l}-0.07 \\
(0.09)\end{array}$ & $\begin{array}{l}-0.03 \\
(0.02)\end{array}$ & $\begin{array}{c}-1.48 * * * * \\
(0.49)\end{array}$ & -196.33 & 3.40 & 146 \\
\hline Canada & $\begin{array}{l}-0.29 \\
(0.37)\end{array}$ & $\begin{array}{c}0.63 * * * \\
(0.19)\end{array}$ & $\begin{array}{c}0.05 \\
(0.06)\end{array}$ & $\begin{array}{c}1.47 * * * \\
(0.47)\end{array}$ & -198.06 & 7.38 & 175 \\
\hline Chile & $\begin{array}{c}0.03 \\
(0.08)\end{array}$ & $\begin{array}{c}0.25^{* *} \\
(0.12)\end{array}$ & $\begin{array}{l}-0.05 \\
(0.05)\end{array}$ & $\begin{array}{c}1.07 * * \\
(0.47)\end{array}$ & -145.62 & 4.52 & 161 \\
\hline China & $\begin{array}{c}-0.09 * * \\
(0.04)\end{array}$ & $\begin{array}{c}0.46^{* * * *} \\
(0.16)\end{array}$ & $\begin{array}{l}-0.15 \\
(0.10)\end{array}$ & $\begin{array}{c}0.91 \\
(0.69)\end{array}$ & -75.61 & 7.24 & 165 \\
\hline Czech Rep. & $\begin{array}{l}-0.03 \\
(0.05)\end{array}$ & $\begin{array}{c}0.69 * * * \\
(0.12)\end{array}$ & $\begin{array}{l}-0.03 \\
(0.07)\end{array}$ & $\begin{array}{c}0.50 \\
(0.55)\end{array}$ & -123.74 & 15.16 & 153 \\
\hline Denmark & $\begin{array}{c}0.38 \\
(0.42)\end{array}$ & $\begin{array}{c}-0.81 * * \\
(0.36)\end{array}$ & $\begin{array}{l}-0.05 \\
(0.14)\end{array}$ & $\begin{array}{c}2.46^{* * *} \\
(0.54)\end{array}$ & -131.14 & 8.44 & 172 \\
\hline Finland & $\begin{array}{c}.007 \\
(0.74)\end{array}$ & $\begin{array}{l}-0.15 \\
(0.81)\end{array}$ & $\begin{array}{l}-0.04 \\
(0.17)\end{array}$ & $\begin{array}{c}2.61 \\
(2.32)\end{array}$ & -15.87 & 5.18 & 58 \\
\hline France & $\begin{array}{c}-2.79 * * * \\
(0.99)\end{array}$ & $\begin{array}{c}12.34 * * * \\
(3.21)\end{array}$ & $\begin{array}{c}0.25 \\
(0.30)\end{array}$ & $\begin{array}{l}-1.51 \\
(1.44)\end{array}$ & -17.65 & 62.13 & 58 \\
\hline Germany & $\begin{array}{c}-3.45 * * \\
(1.52)\end{array}$ & $\begin{array}{c}3.61 * * * \\
(1.38)\end{array}$ & $\begin{array}{l}-0.16 \\
(0.23)\end{array}$ & $\begin{array}{l}-1.12 \\
(1.34)\end{array}$ & -16.72 & 43.44 & 58 \\
\hline Greece & $\begin{array}{c}0.22 \\
(0.20)\end{array}$ & $\begin{array}{c}1.07 \\
(1.21)\end{array}$ & $\begin{array}{c}0.03 \\
(0.12)\end{array}$ & $\begin{array}{c}0.59 \\
(1.24)\end{array}$ & -47.22 & 3.28 & 58 \\
\hline Hungary & $\begin{array}{c}-0.08 * * * \\
(0.03)\end{array}$ & $\begin{array}{c}-0.33 * * * \\
(0.12)\end{array}$ & $\begin{array}{c}-0.04 * * \\
(0.02)\end{array}$ & $\begin{array}{l}-0.55 \\
(0.49)\end{array}$ & -163.86 & 3.91 & 164 \\
\hline India & $\begin{array}{l}-0.06 \\
(0.07)\end{array}$ & $\begin{array}{c}0.24 \\
(0.21)\end{array}$ & $\begin{array}{l}-0.12 \\
(0.09)\end{array}$ & $\begin{array}{c}0.24 \\
(0.72)\end{array}$ & -59.52 & 3.98 & 165 \\
\hline Indonesia & $\begin{array}{l}0.49 * * \\
(0.20)\end{array}$ & $\begin{array}{c}0.74 \\
(1.01)\end{array}$ & $\begin{array}{l}-0.05 \\
(0.11)\end{array}$ & $\begin{array}{c}0.09 \\
(1.12)\end{array}$ & -48.19 & 6.26 & 39 \\
\hline Ireland & $\begin{array}{l}-1.07 \\
(0.95)\end{array}$ & $\begin{array}{l}-0.01 \\
(0.22)\end{array}$ & $\begin{array}{l}-0.16 \\
(0.20)\end{array}$ & $\begin{array}{l}2.46^{*} \\
(1.29)\end{array}$ & -32.90 & 10.97 & 58 \\
\hline Israel & $\begin{array}{c}-0.09 * * \\
(0.03)\end{array}$ & $\begin{array}{c}0.34 * * * \\
(0.11)\end{array}$ & $\begin{array}{c}-0.12^{* *} \\
(0.05)\end{array}$ & $\begin{array}{l}0.87 * \\
(0.47)\end{array}$ & -217.7 & 4.27 & 165 \\
\hline Italy & $\begin{array}{l}0.59 * * \\
(0.26)\end{array}$ & $\begin{array}{l}0.97 * \\
(0.59)\end{array}$ & $\begin{array}{c}-0.21 * * \\
(0.11)\end{array}$ & $\begin{array}{l}-0.18 \\
(1.26)\end{array}$ & -28.62 & 21.20 & 58 \\
\hline Japan & $\begin{array}{l}-0.05 \\
(0.38)\end{array}$ & $\begin{array}{c}0.26 \\
(0.27)\end{array}$ & $\begin{array}{l}-0.08 \\
(0.05)\end{array}$ & $\begin{array}{c}0.20 \\
(0.84)\end{array}$ & -42.85 & 4.81 & 175 \\
\hline Luxembourg & $\begin{array}{c}-0.44 \\
(0.54)\end{array}$ & $\begin{array}{c}0.04 \\
(0.04)\end{array}$ & $\begin{array}{c}0.30 \\
(0.45)\end{array}$ & $\begin{array}{l}-1.48 \\
(1.41)\end{array}$ & -26.51 & 5.04 & \\
\hline Mexico & $\begin{array}{c}-0.05^{* * * *} \\
(0.01)\end{array}$ & $\begin{array}{c}0.12 \\
(0.13)\end{array}$ & $\begin{array}{c}-0.10^{* * * *} \\
(0.03)\end{array}$ & $\begin{array}{l}1.09 * * \\
(0.44)\end{array}$ & -249.92 & 5.54 & 175 \\
\hline Netherlands & $\begin{array}{l}-2.78^{*} \\
(1.52)\end{array}$ & $\begin{array}{c}3.18^{* * * *} \\
(0.82)\end{array}$ & $\begin{array}{c}-0.02 \\
(0.20)\end{array}$ & $\begin{array}{c}0.96 \\
(1.25)\end{array}$ & -36.41 & 23.14 & 58 \\
\hline New Zealand & $\begin{array}{c}0.44 \\
(0.45)\end{array}$ & $\begin{array}{c}0.89 * * \\
(0.42)\end{array}$ & $\begin{array}{c}0.05 \\
(0.05)\end{array}$ & $\begin{array}{c}2.18 * * * \\
(0.63)\end{array}$ & -91.81 & 10.35 & 114 \\
\hline Norway & $\begin{array}{l}0.41 * \\
(0.21)\end{array}$ & $\begin{array}{c}0.43 * * * \\
(0.15)\end{array}$ & $\begin{array}{c}0.06 \\
(0.07)\end{array}$ & $\begin{array}{c}0.66 \\
(0.50)\end{array}$ & -147.84 & 5.28 & 175 \\
\hline Poland & $\begin{array}{c}-0.20 * * * \\
(0.05)\end{array}$ & $\begin{array}{c}0.92 * * * \\
(0.17)\end{array}$ & $\begin{array}{c}0.05 \\
(0.05)\end{array}$ & $\begin{array}{l}-0.82 \\
(0.58)\end{array}$ & -120.66 & 13.94 & 127 \\
\hline Portugal & $\begin{array}{c}-0.02 \\
(0.17)\end{array}$ & $\begin{array}{c}0.92 \\
(0.76)\end{array}$ & $\begin{array}{l}-0.48 * \\
(0.27)\end{array}$ & $\begin{array}{l}2.52 * * \\
(1.05)\end{array}$ & -70.03 & 5.93 & 58 \\
\hline Korea, Rep. & $\begin{array}{c}0.43 \\
(0.64)\end{array}$ & $\begin{array}{l}-0.10 \\
(0.22)\end{array}$ & $\begin{array}{c}0.04 \\
(0.08)\end{array}$ & $\begin{array}{l}1.24 * \\
(0.74)\end{array}$ & -63.46 & 4.94 & 111 \\
\hline Slovenia & $\begin{array}{l}-0.07 \\
(0.15)\end{array}$ & $\begin{array}{c}1.07 \\
(0.98)\end{array}$ & $\begin{array}{l}-0.08 \\
(0.41)\end{array}$ & $\begin{array}{l}2.14 * \\
(1.17)\end{array}$ & -54.70 & 6.81 & 83 \\
\hline
\end{tabular}

-continued in the next page - 
TABLE 2

MONETARY POLICY INTERDEPENDENCE WITH THE US

\begin{tabular}{|c|c|c|c|c|c|c|c|}
\hline \multicolumn{8}{|c|}{-continued from previous page- } \\
\hline Country & Inflation & Growth & Eff. XR & US MP & Log.Lik. & Pseudo $\mathrm{R}^{2}$ & Obs. \\
\hline South Africa & $\begin{array}{c}0.07 \\
(0.05)\end{array}$ & $\begin{array}{c}0.69 * * * \\
(0.15)\end{array}$ & $\begin{array}{c}-0.07 * * * \\
(0.03)\end{array}$ & $\begin{array}{c}0.29 \\
(0.48)\end{array}$ & -160.80 & 8.66 & 175 \\
\hline Spain & $\begin{array}{c}0.83 * * * \\
(0.26)\end{array}$ & $\begin{array}{c}1.81 * * * \\
(0.52)\end{array}$ & $\begin{array}{l}-0.20 \\
(0.20)\end{array}$ & $\begin{array}{l}2.71 * * \\
(1.08)\end{array}$ & -56.01 & 17.36 & 58 \\
\hline Sweden & $\begin{array}{c}0.76 * * * \\
(0.16)\end{array}$ & $\begin{array}{c}1.50 * * * * \\
(0.26)\end{array}$ & $\begin{array}{l}-0.13^{*} \\
(0.07)\end{array}$ & $\begin{array}{l}-0.04 \\
(0.48)\end{array}$ & -144.71 & 14.67 & 175 \\
\hline Switzerland & $\begin{array}{c}-0.86 * * * \\
(0.31)\end{array}$ & $\begin{array}{c}0.35 \\
(0.50)\end{array}$ & $\begin{array}{l}-0.02 \\
(0.09)\end{array}$ & $\begin{array}{l}1.42 * * \\
(0.59)\end{array}$ & -98.76 & 6.71 & 175 \\
\hline Turkey & $\begin{array}{c}.002 \\
(0.01)\end{array}$ & $\begin{array}{c}0.06 \\
(0.16)\end{array}$ & $\begin{array}{c}0.01 \\
(0.02)\end{array}$ & $\begin{array}{l}-0.32 \\
(0.49)\end{array}$ & -241.17 & 0.14 & 162 \\
\hline U.K. & $\begin{array}{c}0.14 \\
(0.14)\end{array}$ & $\begin{array}{c}0.66 * * * \\
(0.21)\end{array}$ & $\begin{array}{c}0.12 \\
(0.08)\end{array}$ & $\begin{array}{c}2.36 * * * \\
(0.51)\end{array}$ & -134.57 & 13.70 & 175 \\
\hline Euro Area & $\begin{array}{c}1.77 * * * \\
(0.67)\end{array}$ & $\begin{array}{l}0.49 * \\
(0.27)\end{array}$ & $\begin{array}{l}-0.21 \\
(0.10)\end{array}$ & $\begin{array}{c}2.66 * * * \\
(0.70)\end{array}$ & -71.94 & 16.09 & 116 \\
\hline
\end{tabular}

NOTES: This table reports results from the estimation of the ordered probit model of $E q$. (4). The dependent variable captures the magnitude and direction of a country's policy rate adjustment on month $t$, and can take 5 different values ("strong decrease", "decrease", "inactivity", "increase", "strong increase"), as described in the main body of the text. The independent variables are lagged, and are the following: Inflation stands for the next year's expected inflation rate minus $2 \%$ (Consensus Economics), Growth for the next year's expected gross domestic product growth minus $2.5 \%$ (Consensus Economics), Eff. XR for the monthly percentage change in a country's effective exchange rate, and US MP is the discrete random variable $y^{U S}$ showing the magnitude and direction of the US monetary policy rate adjustment. For countries participating in the Eurozone, we estimate Eq. (4) separately for each country's policy rate for the period before January 1999. After the introduction of the euro in January 1999, we consider the relationship between US monetary policy rate and the policy rate set by the European Central Bank. For Luxembourg for the period before 1999 we use the policy rate set by the National Bank of Belgium. In the parentheses (.) we report the standard errors of the coefficient estimates.

$* / * * / * * *$ denote significance at $90 \%, 95 \%$, and $99 \%$ confidence levels respectively. 
TABLE 3

MONETARY POLICY RATE SYNCHRONISATION

\begin{tabular}{|c|c|c|c|c|c|}
\hline & $S_{i}$ & $S_{i} \times X_{j, i}^{S Y N}$ & $\begin{array}{c}H_{0}: \beta_{1}+\beta_{2}=0 \\
{[p \text {-value] }}\end{array}$ & $R^{2}(\%)$ & Obs. \\
\hline \multicolumn{6}{|c|}{ Panel A: Time-varying synchronisation } \\
\hline$r_{j, i}$ & $\begin{array}{c}-4.89 * * \\
(-2.35)\end{array}$ & $\begin{array}{l}3.13 * \\
(1.78)\end{array}$ & {$[0.19]$} & 2.08 & 3,771 \\
\hline$r_{j, i}^{3-d a y s}$ & $\begin{array}{l}-4.22^{*} \\
(-1.70)\end{array}$ & $\begin{array}{l}4.09 * \\
(1.86)\end{array}$ & {$[0.94]$} & 1.12 & 3,771 \\
\hline$r_{j, i}^{5-d a y s}$ & $\begin{array}{l}-4.32 * \\
(-1.89)\end{array}$ & $\begin{array}{l}3.91 * \\
(1.92)\end{array}$ & [0.82] & 1.21 & 3,771 \\
\hline \multicolumn{6}{|c|}{ Panel B: Directional model synchronisation } \\
\hline$r_{j, i}$ & $\begin{array}{c}-4.90 * * * \\
(-4.17)\end{array}$ & $\begin{array}{c}2.45 * * \\
(1.99)\end{array}$ & {$[0.00]$} & 1.94 & 3,736 \\
\hline$r_{j, i}^{3-d a y s}$ & $\begin{array}{c}-3.61 * * * \\
(-3.96)\end{array}$ & $\begin{array}{l}2.44 * * \\
(2.35)\end{array}$ & [0.10] & 0.73 & 3,736 \\
\hline$r_{j, i}^{5-d a y s}$ & $\begin{array}{c}-3.84 * * \\
(-3.69)\end{array}$ & $\begin{array}{l}2.67 * * \\
(2.37)\end{array}$ & {$[0.07]$} & 0.85 & 3,736 \\
\hline
\end{tabular}

NOTES: In this table, we report results from the estimation of $E q$. (5). $X^{S Y N}$ is a $0-1$ dummy variable taking the value of 1 on days when the monetary policy conditions in a country are similar to those in the US, and zero otherwise. In Panel A, we report the results when $X^{S Y N}$ is constructed using the time-varying definition of a country's monetary policy conditions. Specifically, the monetary policy conditions in a country are tightening (easing) for a period which starts on a month with a policy rate hike (cut) and continues until there is a rate cut (hike), while after 12 months of unchanged policy rates we assume a period of monetary policy inactivity. In panel B, $X^{S Y N}$ takes the value of 1 for those countries which are more likely to adjust their policy rates in the same direction as the US policy rate, identified by Bergin and Jordà's (2004) model described in the main body of the text. In column [p-value], we report the level of significance for the null hypothesis: $H_{0}: \beta_{1}+\beta_{2}=0$. Coefficient estimates are obtained by the OLS method, and t-statistics (.) in Panel A are calculated using the two-dimensional clustered standard errors of Petersen (2009), while in Panel B we report bootstrap t-statistics.

$* / * * / * * *$ denote significance at $90 \%, 95 \%$, and $99 \%$ confidence levels respectively. 


\section{TABLE 4}

\section{OTHER FACTORS OF INTERACTION}

\begin{tabular}{|c|c|c|c|c|c|c|c|}
\hline \multicolumn{3}{|c|}{$S_{i}$} & Coefficient & t-stat & $\begin{array}{c}H_{0}: \beta_{1}+\beta_{2 / 3 / 4}=0 \\
{[p \text {-value }]}\end{array}$ & $R^{2}(\%)$ & Obs. \\
\hline \multicolumn{8}{|c|}{ (a) real integration proxies } \\
\hline $\begin{array}{l}\text { Trade } \\
\text { (row) }\end{array}$ & $\begin{array}{c}-5.89 * * \\
(-2.35)\end{array}$ & $\begin{array}{l}\text { (1) } X^{\text {HIGH }} \\
\text { (2) } X^{\text {MED }} \\
\text { (3) } X^{\text {LOW }}\end{array}$ & $\begin{array}{c}4.06^{*} \\
3.09 \\
2.23\end{array}$ & $\begin{array}{l}(1.89) \\
(1.44) \\
(1.52)\end{array}$ & $\begin{array}{l}{[0.59]} \\
{[0.32]} \\
{[0.06]}\end{array}$ & 2.13 & 3,771 \\
\hline $\begin{array}{l}\text { Exports to } \\
\text { US }\end{array}$ & $\begin{array}{c}-5.06 * * \\
(-2.36)\end{array}$ & $\begin{array}{l}\text { (1) } X^{\text {HIGH }} \\
\text { (2) } X^{\text {MED }} \\
\text { (3) } X^{\text {LOW }}\end{array}$ & $\begin{array}{c}4.59 * * \\
3.98 * \\
1.64\end{array}$ & $\begin{array}{l}(2.28) \\
(1.71) \\
(0.91)\end{array}$ & $\begin{array}{l}{[0.76]} \\
{[0.63]} \\
{[0.00]}\end{array}$ & 2.26 & 3,691 \\
\hline \multicolumn{8}{|c|}{ (b) financial integration proxies } \\
\hline Bank & $\begin{array}{l}-4.89 * * \\
(-2.35)\end{array}$ & $\begin{array}{l}\text { (1) } X^{\text {HIGH }} \\
\text { (2) } X^{\text {MED }} \\
\text { (3) } X^{\text {LOW }}\end{array}$ & $\begin{array}{c}4.07 * \\
3.31 \\
1.59\end{array}$ & $\begin{array}{l}(1.74) \\
(1.55) \\
(0.70)\end{array}$ & $\begin{array}{l}{[0.64]} \\
{[0.37]} \\
{[0.16]}\end{array}$ & 2.16 & 3,771 \\
\hline $\begin{array}{l}\text { Lending } \\
\text { from US }\end{array}$ & $\begin{array}{l}-5.20 * \\
(-1.95)\end{array}$ & $\begin{array}{l}\text { (1) } X^{\text {HIGH }} \\
\text { (2) } X^{\text {MED }} \\
\text { (3) } X^{\text {LOW }}\end{array}$ & $\begin{array}{c}3.70 \\
5.05^{* *} \\
3.00\end{array}$ & $\begin{array}{l}(1.40) \\
(2.45) \\
(1.05)\end{array}$ & $\begin{array}{l}{[0.41]} \\
{[0.93]} \\
{[0.34]}\end{array}$ & 1.83 & 3,057 \\
\hline FDI & $\begin{array}{c}-5.19 * * \\
(-2.23)\end{array}$ & $\begin{array}{l}\text { (1) } X^{\text {HIGH }} \\
\text { (2) } X^{\text {MED }} \\
\text { (3) } X^{\text {LOW }}\end{array}$ & $\begin{array}{c}4.39 * \\
4.60 * * \\
1.55\end{array}$ & $\begin{array}{l}(1.90) \\
(2.05) \\
(0.61)\end{array}$ & $\begin{array}{l}{[0.65]} \\
{[0.71]} \\
{[0.13]}\end{array}$ & 2.50 & 3,379 \\
\hline $\begin{array}{c}\text { FDI } \\
\text { (US stock) }\end{array}$ & $\begin{array}{c}-4.98 * * \\
(-2.40)\end{array}$ & $\begin{array}{l}\text { (1) } X^{\text {HIGH }} \\
\text { (2) } X^{\text {MED }} \\
\text { (3) } X^{\text {LOW }}\end{array}$ & $\begin{array}{c}4.59 * * \\
4.28 * \\
1.10\end{array}$ & $\begin{array}{l}(2.26) \\
(1.92) \\
(0.58)\end{array}$ & $\begin{array}{l}{[0.80]} \\
{[0.73]} \\
{[0.01]}\end{array}$ & 2.39 & 3,654 \\
\hline $\begin{array}{l}\text { Portfolio } \\
\text { Equity }\end{array}$ & $\begin{array}{c}-4.98 * * \\
(-2.35)\end{array}$ & $\begin{array}{l}\text { (1) } X^{\text {HIGH }} \\
\text { (2) } X^{\text {MED }} \\
\text { (3) } X^{\text {LOW }}\end{array}$ & $\begin{array}{c}3.82 * \\
4.85 * * \\
-0.06\end{array}$ & $\begin{array}{l}(1.70) \\
(2.16) \\
(-0.05)\end{array}$ & $\begin{array}{l}{[0.55]} \\
{[0.98]} \\
{[0.00]}\end{array}$ & 2.39 & 3,771 \\
\hline $\begin{array}{l}\text { Portfolio } \\
\text { Debt }\end{array}$ & $\begin{array}{c}-4.89 * * \\
(-2.35)\end{array}$ & $\begin{array}{l}\text { (1) } X^{\text {HIGH }} \\
\text { (2) } X^{\text {MED }} \\
\text { (3) } X^{\text {LOW }}\end{array}$ & $\begin{array}{c}4.04 * \\
3.95 * \\
0.40\end{array}$ & $\begin{array}{l}(1.67) \\
(1.84) \\
(0.21)\end{array}$ & $\begin{array}{l}{[0.67]} \\
{[0.60]} \\
{[0.01]}\end{array}$ & 2.26 & 3,771 \\
\hline $\begin{array}{l}\text { US equity } \\
\text { investment }\end{array}$ & $\begin{array}{l}-6.44 * \\
(-1.79)\end{array}$ & $\begin{array}{l}\text { (1) } X^{\mathrm{HIGH}} \\
\text { (2) } \mathrm{X}^{\mathrm{MED}} \\
\text { (3) } \mathrm{X}^{\mathrm{LOW}}\end{array}$ & $\begin{array}{c}7.93 * * \\
10.51 * * * \\
3.49\end{array}$ & $\begin{array}{l}(2.40) \\
(2.94) \\
(0.86)\end{array}$ & $\begin{array}{l}{[0.43]} \\
{[0.03]} \\
{[0.34]}\end{array}$ & 3.86 & 2,044 \\
\hline
\end{tabular}

\begin{tabular}{|c|c|c|c|c|c|c|c|}
\hline \multicolumn{8}{|c|}{ (c) Exchange rates flexibility } \\
\hline $\begin{array}{l}\text { XR Regime } \\
\text { Classification }\end{array}$ & $\begin{array}{c}-4.90 * * \\
(-2.34)\end{array}$ & $\begin{array}{l}\text { (1) } X^{\text {FLEX }} \\
\text { (2) } X^{\text {FIXED }}\end{array}$ & $\begin{array}{l}2.32 \\
3.70\end{array}$ & $\begin{array}{l}(1.46) \\
(1.59)\end{array}$ & $\begin{array}{l}{[0.07]} \\
{[0.52]}\end{array}$ & 2.11 & 3,762 \\
\hline XR Volatility & $\begin{array}{l}-4.73^{* *} \\
(-2.11)\end{array}$ & $\begin{array}{l}\text { (1) } \mathrm{X}^{\mathrm{HIGH}} \\
\text { (2) } \mathrm{X}^{\mathrm{MED}} \\
\text { (3) } \mathrm{X}^{\mathrm{LOW}}\end{array}$ & $\begin{array}{c}-1.34 \\
4.79 * * * \\
2.98 \\
\end{array}$ & $\begin{array}{l}(-0.53) \\
(2.65) \\
(1.43) \\
\end{array}$ & $\begin{array}{l}{[0.01]} \\
{[0.98]} \\
{[0.31]} \\
\end{array}$ & 2.19 & 3,552 \\
\hline \multicolumn{8}{|c|}{ Panel B: Directional model synchronisation } \\
\hline \multicolumn{8}{|c|}{ (a) real integration proxies } \\
\hline $\begin{array}{l}\text { Trade } \\
\text { (row) }\end{array}$ & $\begin{array}{c}-4.90 * * * \\
(-4.19)\end{array}$ & $\begin{array}{l}\text { (1) } X^{\mathrm{HIGH}} \\
\text { (2) } \mathrm{X}^{\mathrm{MED}} \\
\text { (3) } \mathrm{X}^{\mathrm{LOW}}\end{array}$ & $\begin{array}{c}2.22 * \\
2.77 * * \\
2.43\end{array}$ & $\begin{array}{l}(1.75) \\
(2.10) \\
(1.63)\end{array}$ & $\begin{array}{l}{[0.00]} \\
{[0.05]} \\
{[0.04]}\end{array}$ & 1.94 & 3,736 \\
\hline $\begin{array}{l}\text { Exports to } \\
\text { US }\end{array}$ & $\begin{array}{c}-4.99 * * * \\
(-4.09)\end{array}$ & $\begin{array}{l}\text { (1) } \mathrm{X}^{\mathrm{HIGH}} \\
\text { (2) } \mathrm{X}^{\mathrm{MED}} \\
\text { (3) } \mathrm{X}^{\mathrm{LOW}}\end{array}$ & $\begin{array}{c}2.94 * * \\
1.93 \\
2.36^{*}\end{array}$ & $\begin{array}{l}(2.10) \\
(1.31) \\
(1.70)\end{array}$ & $\begin{array}{l}{[0.02]} \\
{[0.05]} \\
{[0.00]}\end{array}$ & 1.99 & 3,688 \\
\hline
\end{tabular}




\section{TABLE 4}

\section{OTHER FACTORS OF INTERACTION}

\begin{tabular}{|c|c|c|c|c|c|c|c|}
\hline & $S_{i}$ & & Coefficient & $t$-stat & $\begin{array}{c}H_{0}: \beta_{1}+\beta_{2 / 3 / 4}=0 \\
\text { [p-value] }\end{array}$ & $R^{2}(\%)$ & Obs. \\
\hline \multicolumn{8}{|c|}{ (b) financial integration proxies } \\
\hline Bank & $\begin{array}{c}-4.90 * * * \\
(-4.17)\end{array}$ & $\begin{array}{l}\text { (1) } X^{\mathrm{HIGH}} \\
\text { (2) } \mathrm{X}^{\mathrm{MED}} \\
\text { (3) } \mathrm{X}^{\mathrm{LOW}}\end{array}$ & $\begin{array}{c}1.98 \\
2.77^{* *} \\
3.35\end{array}$ & $\begin{array}{l}(1.54) \\
(2.16) \\
(1.62)\end{array}$ & $\begin{array}{l}{[0.00]} \\
{[0.06]} \\
{[0.20]}\end{array}$ & 1.96 & 3,736 \\
\hline $\begin{array}{l}\text { Lending } \\
\text { from US }\end{array}$ & $\begin{array}{r}-4.77 * * \\
(-3.18)\end{array}$ & $\begin{array}{l}\text { (1) } X^{\text {HIGH }} \\
\text { (2) } X^{\text {MED }} \\
\text { (3) } X^{\text {LOW }}\end{array}$ & $\begin{array}{l}2.27 \\
2.88 \\
1.96\end{array}$ & $\begin{array}{l}(1.33) \\
(1.49) \\
(0.98)\end{array}$ & $\begin{array}{l}{[0.01]} \\
{[0.19]} \\
{[0.06]}\end{array}$ & 1.55 & 3,046 \\
\hline FDI & $\begin{array}{r}-4.67 * * \\
(-2.39)\end{array}$ & $\begin{array}{l}\text { (1) } X^{\mathrm{HIGH}} \\
\text { (2) } \mathrm{X}^{\mathrm{MED}} \\
\text { (3) } \mathrm{X}^{\mathrm{LOW}}\end{array}$ & $\begin{array}{c}1.25 \\
2.83 * \\
2.72\end{array}$ & $\begin{array}{l}(0.65) \\
(1.76) \\
(1.26)\end{array}$ & $\begin{array}{l}{[0.00]} \\
{[0.08]} \\
{[0.10]}\end{array}$ & 1.97 & 3,293 \\
\hline $\begin{array}{c}\text { FDI } \\
\text { (US stock) }\end{array}$ & $\begin{array}{c}-5.25 * * * \\
(-4.70)\end{array}$ & $\begin{array}{l}\text { (1) } X^{\text {HIGH }} \\
\text { (2) } X^{\text {MED }} \\
\text { (3) } X^{\text {LOW }}\end{array}$ & $\begin{array}{c}3.30 * * * \\
3.06 * * \\
1.46\end{array}$ & $\begin{array}{l}(2.58) \\
(2.18) \\
(1.11)\end{array}$ & $\begin{array}{l}{[0.02]} \\
{[0.04]} \\
{[0.01]}\end{array}$ & 2.24 & 3,608 \\
\hline $\begin{array}{l}\text { Portfolio } \\
\text { Equity }\end{array}$ & $\begin{array}{c}-4.90 * * * \\
(-4.30)\end{array}$ & $\begin{array}{l}\text { (1) } X^{\text {HIGH }} \\
\text { (2) } X^{\text {MED }} \\
\text { (3) } X^{\text {LOW }}\end{array}$ & $\begin{array}{c}1.82 \\
3.00 * * \\
2.78\end{array}$ & $\begin{array}{l}(1.48) \\
(2.20) \\
(1.53)\end{array}$ & $\begin{array}{l}{[0.00]} \\
{[0.04]} \\
{[0.18]}\end{array}$ & 1.97 & 3,736 \\
\hline $\begin{array}{l}\text { Portfolio } \\
\text { Debt }\end{array}$ & $\begin{array}{c}-4.90 * * * \\
(-4.22)\end{array}$ & $\begin{array}{l}\text { (1) } X^{\mathrm{HIGH}} \\
\text { (2) } \mathrm{X}^{\mathrm{MED}} \\
\text { (3) } \mathrm{X}^{\mathrm{LOW}}\end{array}$ & $\begin{array}{c}2.22 * \\
2.94 * * \\
1.70\end{array}$ & $\begin{array}{l}(1.75) \\
(2.11) \\
(0.93)\end{array}$ & $\begin{array}{l}{[0.00]} \\
{[0.05]} \\
{[0.01]}\end{array}$ & 1.95 & 3,736 \\
\hline $\begin{array}{l}\text { US equity } \\
\text { investment }\end{array}$ & $\begin{array}{l}-3.93 * * \\
(-2.09)\end{array}$ & $\begin{array}{l}\text { (1) } X^{\text {HIGH }} \\
\text { (2) } X^{\text {MED }} \\
\text { (3) } X^{\text {LOW }}\end{array}$ & $\begin{array}{l}1.60 \\
2.86 \\
2.11\end{array}$ & $\begin{array}{l}(0.70) \\
(1.16) \\
(0.94)\end{array}$ & $\begin{array}{l}{[0.09]} \\
{[0.51]} \\
{[0.12]}\end{array}$ & 1.20 & 2,066 \\
\hline \multicolumn{8}{|c|}{ (c) Exchange rates flexibility } \\
\hline $\begin{array}{l}\text { XR Regime } \\
\text { Classification }\end{array}$ & $\begin{array}{c}-4.90 * * * \\
(-4.20)\end{array}$ & $\begin{array}{l}\text { (1) } X^{\text {FLEX }} \\
\text { (2) } X^{\text {FIXED }}\end{array}$ & $\begin{array}{l}3.25^{* *} \\
2.06^{*}\end{array}$ & $\begin{array}{l}(2.18) \\
(1.69)\end{array}$ & $\begin{array}{l}{[0.06]} \\
{[0.00]}\end{array}$ & 1.97 & 3,736 \\
\hline XR Volatility & $\begin{array}{c}-4.30 * * * \\
(-3.59)\end{array}$ & $\begin{array}{l}\text { (1) } X^{\text {HIGH }} \\
\text { (2) } X^{\text {MED }} \\
\text { (3) } X^{\text {LOW }}\end{array}$ & $\begin{array}{c}0.60 \\
4.41 * * * \\
-0.90\end{array}$ & $\begin{array}{l}(0.31) \\
(2.95) \\
(-0.54)\end{array}$ & $\begin{array}{l}{[0.01]} \\
{[0.91]} \\
{[0.00]}\end{array}$ & 1.99 & 3,568 \\
\hline
\end{tabular}

NOTES: In this table we report results from the estimation of equation Eq. (6). This is a pooled regression of daily equity returns of 35 global equity price indices $(r)$ on the market-based proxy for US monetary policy shocks $(S)$ and 3 interactive terms on the 118 event days described in the main body of the text, and is written as follows:

$r_{j, i}=c+\beta_{1} S_{i}+\beta_{2} S_{i} X_{j, i}^{S Y N} X_{j, i}^{L O W}+\beta_{3} S_{i} X_{j, i}^{S Y N} X_{j, i}^{M E D}+\beta_{4} S_{i} X_{j, i}^{S Y N} X_{j, i}^{H I G H}+\varepsilon_{j, i}$

$X^{L O W}, X^{M E D}, X^{H I G H}$ are $0-1$ dummy variables taking the value of 1 if country $j$ at time $i$ is among the one third of the countries from our sample which has the lowest/medium/highest value of the determinant shown in the first column of this Table, and zero otherwise. Detailed information about the dummy variables construction can be found in Table A.3 of the Appendix. The monetary policy synchronisation dummy $X^{S Y N}$ takes the two alternative definitions which can be found in the main body of the text. In column [ $p$-value], we report the level of significance for the null hypothesis: $H_{0}: \beta_{1}+\beta_{2 / 3 / 4}=0$. Coefficient estimates are obtained by the OLS method, and t-statistics (.) in Panel A are calculated using the two-dimensional clustered standard errors of Petersen (2009), while in Panel B we report bootstrap t-statistics.

$* / * * * * *$ denote significance at $90 \%, 95 \%$, and $99 \%$ confidence levels respectively. 
TABLE A.1

POLICY RATE DATA

\begin{tabular}{|c|c|c|c|c|c|c|c|}
\hline Country & Policy Rate & $\begin{array}{l}\text { Sample } \\
\text { from }\end{array}$ & $\overline{k_{l}}$ & $\bar{~} k_{2}$ & $\overline{k_{3}}$ & $\bar{k}_{4}$ & $k_{5}$ \\
\hline Australia & Cash Rate Target & $01 / 1994$ & $\Delta r \leq-0.5$ & $-0.5<\Delta r<0$ & $\Delta r=0$ & $0<\Delta r<0.5$ & $\Delta r \geq 0.5$ \\
\hline Austria & $\begin{array}{l}\text { Discount Rate / Short } \\
\text { Term Euro Repo Rate }\end{array}$ & $01 / 1994$ & $\Delta r \leq-0.5$ & $-0.5<\Delta r<0$ & $\Delta r=0$ & $0<\Delta r<0.5$ & $\Delta r \geq 0.5$ \\
\hline Belgium & $\begin{array}{l}\text { Discount Rate / Short } \\
\text { Term Euro Repo Rate }\end{array}$ & $01 / 1994$ & $\Delta r \leq-0.5$ & $-0.5<\Delta r<0$ & $\Delta r=0$ & $0<\Delta r<0.5$ & $\Delta r \geq 0.5$ \\
\hline Brazil & Selic Target Rate & $07 / 1996$ & $\Delta r<-0.75$ & $-0.75 \leq \Delta r<0$ & $\Delta r=0$ & $0<\Delta r \leq 0.75$ & $\Delta r>0.75$ \\
\hline Canada & Target Rate & $01 / 1994$ & $\Delta r \leq-0.5$ & $-0.5<\Delta r<0$ & $\Delta r=0$ & $0<\Delta r<0.5$ & $\Delta r \geq 0.5$ \\
\hline Chile & $\begin{array}{l}\text { Central Bank of Chile } \\
\text { Monetary Policy Rate }\end{array}$ & $05 / 1995$ & $\Delta r \leq-0.5$ & $-0.5<\Delta r<0$ & $\Delta r=0$ & $0<\Delta r<0.5$ & $\Delta r \geq 0.5$ \\
\hline China & 1 year Major Loan Rate & $01 / 1994$ & $\Delta r<-0.75$ & $-0.75 \leq \Delta r<0$ & $\Delta r=0$ & $0<\Delta r \leq 0.75$ & $\Delta r>0.75$ \\
\hline Czech Rep. & 2 week Repo Rate & $12 / 1995$ & $\Delta r \leq-0.5$ & $-0.5<\Delta r<0$ & $\Delta r=0$ & $0<\Delta r<0.5$ & $\Delta r \geq 0.5$ \\
\hline Denmark & Discount rate & 01/1994 & $\Delta r \leq-0.5$ & $-0.5<\Delta r<0$ & $\Delta r=0$ & $0<\Delta r<0.5$ & $\Delta r \geq 0.5$ \\
\hline Finland & $\begin{array}{c}\text { Official Base Rate } \\
\text { Average Cost Of Funds }\end{array}$ & 01/1994 & $\Delta r \leq-0.5$ & $-0.5<\Delta r<0$ & $\Delta r=0$ & $0<\Delta r<0.5$ & $\Delta r \geq 0.5$ \\
\hline France & $\begin{array}{c}\text { For Banks / Euro Repo } \\
\text { Rate }\end{array}$ & 01/1994 & $\Delta r \leq-0.5$ & $-0.5<\Delta r<0$ & $\Delta r=0$ & $0<\Delta r<0.5$ & $\Delta r \geq 0.5$ \\
\hline Germany & $\begin{array}{l}\text { Discount Rate / Short } \\
\text { Term Euro Repo Rate }\end{array}$ & 01/1994 & $\Delta r \leq-0.5$ & $-0.5<\Delta r<0$ & $\Delta r=0$ & $0<\Delta r<0.5$ & $\Delta r \geq 0.5$ \\
\hline Greece & $\begin{array}{l}\text { Discount Rate / Short } \\
\text { Term Euro Repo Rate }\end{array}$ & $01 / 1994$ & $\Delta r \leq-0.5$ & $-0.5<\Delta r<0$ & $\Delta r=0$ & $0<\Delta r<0.5$ & $\Delta r \geq 0.5$ \\
\hline Hungary & Central Bank Base Rate & 01/1994 & $\Delta r<-0.75$ & $-0.75 \leq \Delta r<0$ & $\Delta r=0$ & $0<\Delta r \leq 0.75$ & $\Delta r>0.75$ \\
\hline India & Bank Rate & 01/1994 & $\Delta r<-0.75$ & $-0.75 \leq \Delta r<0$ & $\Delta r=0$ & $0<\Delta r \leq 0.75$ & $\Delta r>0.75$ \\
\hline Indonesia & BI Rate & $06 / 2005$ & $\Delta r \leq-0.5$ & $-0.5<\Delta r<0$ & $\Delta r=0$ & $0<\Delta r<0.5$ & $\Delta r \geq 0.5$ \\
\hline Ireland & $\begin{array}{l}\text { Discount Rate / Short } \\
\text { Term Euro Repo Rate }\end{array}$ & $01 / 1994$ & $\Delta r \leq-0.5$ & $-0.5<\Delta r<0$ & $\Delta r=0$ & $0<\Delta r<0.5$ & $\Delta r \geq 0.5$ \\
\hline Israel & Headline Rate & $01 / 1994$ & $\Delta r \leq-0.5$ & $-0.5<\Delta r<0$ & $\Delta r=0$ & $0<\Delta r<0.5$ & $\Delta r \geq 0.5$ \\
\hline Italy & $\begin{array}{l}\text { Discount Rate / Short } \\
\text { Term Euro Repo Rate }\end{array}$ & $01 / 1994$ & $\Delta r \leq-0.5$ & $-0.5<\Delta r<0$ & $\Delta r=0$ & $0<\Delta r<0.5$ & $\Delta r \geq 0.5$ \\
\hline Japan & $\begin{array}{c}\text { Overnight Call Money } \\
\text { Rate }\end{array}$ & $01 / 1994$ & $\Delta r \leq-0.5$ & $-0.5<\Delta r<0$ & $\Delta r=0$ & $0<\Delta r<0.5$ & $\Delta r \geq 0.5$ \\
\hline Luxembourg & Discount Rate/Base Rate & 01/1994 & $\Delta r \leq-0.5$ & $-0.5<\Delta r<0$ & $\Delta r=0$ & $0<\Delta r<0.5$ & $\Delta r \geq 0.5$ \\
\hline Mexico & CETE Rate 28 day & $01 / 1994$ & $\Delta r<-0.75$ & $-0.75 \leq \Delta r<0$ & $\Delta r=0$ & $0<\Delta r \leq 0.75$ & $\Delta r>0.75$ \\
\hline Netherlands & $\begin{array}{l}\text { Credit Advances / Short } \\
\text { Term Euro Repo Rate }\end{array}$ & $01 / 1994$ & $\Delta r \leq-0.5$ & $-0.5<\Delta r<0$ & $\Delta r=0$ & $0<\Delta r<0.5$ & $\Delta r \geq 0.5$ \\
\hline New Zealand & Official Cash Rate Target & 03/1999 & $\Delta r \leq-0.5$ & $-0.5<\Delta r<0$ & $\Delta r=0$ & $0<\Delta r<0.5$ & $\Delta r \geq 0.5$ \\
\hline Norway & Sight Deposit Rate & 01/1994 & $\Delta r \leq-0.5$ & $-0.5<\Delta r<0$ & $\Delta r=0$ & $0<\Delta r<0.5$ & $\Delta r \geq 0.5$ \\
\hline Poland & Reference Rate & $02 / 1998$ & $\Delta r \leq-0.5$ & $-0.5<\Delta r<0$ & $\Delta r=0$ & $0<\Delta r<0.5$ & $\Delta r \geq 0.5$ \\
\hline Portugal & $\begin{array}{l}\text { Discount Rate / Short } \\
\text { Term Euro Repo Rate }\end{array}$ & 01/1994 & $\Delta r \leq-0.5$ & $-0.5<\Delta r<0$ & $\Delta r=0$ & $0<\Delta r<0.5$ & $\Delta r \geq 0.5$ \\
\hline Korea, Rep. & Base Rate & 05/1999 & $\Delta r \leq-0.5$ & $-0.5<\Delta r<0$ & $\Delta r=0$ & $0<\Delta r<0.5$ & $\Delta r \geq 0.5$ \\
\hline Slovenia & $\begin{array}{l}\text { Discount Rate / Short } \\
\text { Term Euro Repo Rate }\end{array}$ & $10 / 2001$ & $\Delta r \leq-0.5$ & $-0.5<\Delta r<0$ & $\Delta r=0$ & $0<\Delta r<0.5$ & $\Delta r \geq 0.5$ \\
\hline South Africa & Discount Rate & $01 / 1994$ & $\Delta r<-0.75$ & $-0.75 \leq \Delta r<0$ & $\Delta r=0$ & $0<\Delta r \leq 0.75$ & $\Delta r>0.75$ \\
\hline Spain & $\begin{array}{l}\text { Discount Rate / Short } \\
\text { Term Euro Repo Rate }\end{array}$ & $01 / 1994$ & $\Delta r \leq-0.5$ & $-0.5<\Delta r<0$ & $\Delta r=0$ & $0<\Delta r<0.5$ & $\Delta r \geq 0.5$ \\
\hline Sweden & Repo Rate & $01 / 1994$ & $\Delta r \leq-0.5$ & $-0.5<\Delta r<0$ & $\Delta r=0$ & $0<\Delta r<0.5$ & $\Delta r \geq 0.5$ \\
\hline Switzerland & $\begin{array}{l}\text { 3-month Libor Target } \\
\text { Rate }\end{array}$ & 01/1994 & $\Delta r \leq-0.5$ & $-0.5<\Delta r<0$ & $\Delta r=0$ & $0<\Delta r<0.5$ & $\Delta r \geq 0.5$ \\
\hline Turkey & $\begin{array}{c}\text { Overnight Borrowing } \\
\text { Rate }\end{array}$ & $01 / 1994$ & $\Delta r<-0.75$ & $-0.75 \leq \Delta r<0$ & $\Delta r=0$ & $0<\Delta r \leq 0.75$ & $\Delta r>0.75$ \\
\hline U.K. & Base Rate & $01 / 1994$ & $\Delta r \leq-0.5$ & $-0.5<\Delta r<0$ & $\Delta r=0$ & $0<\Delta r<0.5$ & $\Delta r \geq 0.5$ \\
\hline U.S. & $\begin{array}{c}\text { Federal Funds Target } \\
\text { Rate }\end{array}$ & $01 / 1994$ & $\Delta r \leq-0.5$ & $-0.5<\Delta r<0$ & $\Delta r=0$ & $0<\Delta r<0.5$ & $\Delta r \geq 0.5$ \\
\hline
\end{tabular}

NOTES: For Euro area countries we use national policy rates until December 1998 (December 2000 for Greece and December 2006 for Slovenia), when these countries pursued their own monetary policy. After the introduction of the euro we use the policy rate set by the ECB. Until December 1998 Luxembourg's monetary policy rate is set by the National Bank of Belgium. 


\begin{tabular}{|c|c|c|c|c|c|}
\hline \multicolumn{6}{|c|}{$\begin{array}{l}\text { TABLE A.2 } \\
\text { MARGINAL EFFECTS OF US MONETARY POLICY }\end{array}$} \\
\hline Country & $k_{l}$ & $k_{2}$ & $k_{3}$ & $k_{4}$ & $k_{5}$ \\
\hline \multirow{2}{*}{ Australia } & -0.06 & -0.05 & -0.07 & 0.14 & 0.04 \\
\hline & {$[0.08]$} & {$[0.10]$} & {$[0.24]$} & {$[0.05]$} & {$[0.15]$} \\
\hline \multirow{2}{*}{ Canada } & -0.11 & -0.34 & 0.10 & 0.24 & 0.11 \\
\hline & {$[0.02]$} & {$[0.00]$} & {$[0.14]$} & {$[0.00]$} & {$[0.01]$} \\
\hline \multirow{2}{*}{ Chile } & -0.11 & -0.26 & 5 & 0.30 & 0.08 \\
\hline & {$[0.04]$} & {$[0.03]$} & $\begin{array}{ll}- & - \\
\end{array}$ & {$[0.03]$} & {$[0.06]$} \\
\hline \multirow{2}{*}{ Denmark } & -0.20 & -0.22 & 0.01 & 0.35 & 0.06 \\
\hline & {$[0.00]$} & {$[0.00]$} & {$[0.98]$} & {$[0.00]$} & {$[0.10]$} \\
\hline \multirow{2}{*}{ Ireland } & -0.19 & -0.29 & 0.36 & & 0.12 \\
\hline & {$[0.10]$} & {$[0.08]$} & [0.14] & - & {$[0.21]$} \\
\hline \multirow{2}{*}{ Israel } & -0.19 & -0.16 & 0.15 & 0.10 & 0.09 \\
\hline & {$[0.07]$} & {$[0.08]$} & {$[0.08]$} & [0.09] & [0.09] \\
\hline \multirow{2}{*}{ Mexico } & -0.35 & -0.09 & 0.01 & 0.13 & 0.29 \\
\hline & {$[0.01]$} & {$[0.06]$} & [0.19] & {$[0.03]$} & [0.01] \\
\hline \multirow{2}{*}{ New Zealand } & -0.07 & -0.18 & -0.28 & 0.45 & 0.08 \\
\hline & [0.11] & {$[0.02]$} & {$[0.05]$} & {$[0.00]$} & [0.11] \\
\hline \multirow{2}{*}{ Portugal } & -0.39 & -0.59 & 0.51 & 0.25 & 0.21 \\
\hline & {$[0.04]$} & {$[0.05]$} & [0.04] & {$[0.10]$} & [0.11] \\
\hline \multirow{2}{*}{ Korea, Rep. } & -0.02 & -0.13 & -0.05 & 0.20 & 正 \\
\hline & {$[0.36]$} & [0.12] & {$[0.50]$} & [0.09] & - \\
\hline \multirow{2}{*}{ Slovenia } & -0.31 & -0.30 & 0.40 & 0.16 & 0.06 \\
\hline & [0.09] & {$[0.12]$} & {$[0.13]$} & {$[0.16]$} & {$[0.36]$} \\
\hline \multirow{2}{*}{ Spain } & -0.35 & -0.63 & 0.87 & 0.05 & 0.07 \\
\hline & [0.04] & [0.03] & {$[0.02]$} & {$[0.38]$} & [0.33] \\
\hline \multirow{2}{*}{ Switzerland } & -0.16 & -0.01 & -.006 & 0.12 & 0.05 \\
\hline & {$[0.02]$} & [0.35] & [0.91] & {$[0.03]$} & [0.08] \\
\hline \multirow{2}{*}{ U.K. } & -0.04 & -0.37 & -0.02 & 0.38 & 0.05 \\
\hline & [0.14] & {$[0.00]$} & [0.87] & {$[0.00]$} & {$[0.12]$} \\
\hline \multirow{2}{*}{ Euro Area } & -0.11 & -0.09 & -0.24 & 0.39 & 0.04 \\
\hline & {$[0.06]$} & [0.09] & {$[0.08]$} & {$[0.00]$} & {$[0.22]$} \\
\hline
\end{tabular}

NOTES: This table shows the marginal effects of $y_{t}$ from the ordered probit model in Eq. (4) and the corresponding level of significance [.]. Marginal effects are calculated only for those countries whose policy rates are more likely to adjust their policy rates in the same direction as the Federal Reserve's policy rate, as they have been identified in Table 2. 


\section{TABLE A.3 DATA APPENDIX}

\begin{tabular}{|c|c|}
\hline Dummy Variable & Definition \\
\hline $\begin{array}{l}\text { Trade (row) / } \\
\text { Exports to the US }\end{array}$ & $\begin{array}{l}0-1 \text { dummy variable taking the value of } 1 \text { for a country which at time } i \text { is among the one-third of } \\
\text { the countries from our sample with the lowest/medium/highest }\left(X^{L O W} / X^{M E D} / X^{H I G H}\right) \text { level of trade } \\
\text { with the rest of the world / exports to the US as a percentage of their GDP, and zero otherwise. } \\
\text { Trade is the sum of exports and imports of goods and services measured as a percentage of GDP. } \\
\text { [Source: World bank; IMF Direction of Trade Statistics; annual frequency] }\end{array}$ \\
\hline
\end{tabular}

FDI / FDI (US stock)

$0-1$ dummy variable taking the value of 1 for a country which at time $i$ is among the one-third of the countries from our sample with the lowest/medium/highest $\left(X^{L O W} / X^{M E D} / X^{H I G H}\right)$ level of foreign direct investment positions (outward + inward) / US direct investment position as a percentage of their GDP, and zero otherwise. [OECD; annual frequency]

Bank

0-1 dummy variable taking the value of 1 for a country which at time $i$ is among the one-third of the countries from our sample whose banks have the lowest/medium/highest $\left(X^{L O W} / X^{M E D} / X^{H I G H}\right)$ level of external positions (assets and liabilities) with the rest of the world, and zero otherwise. [BIS locational banking statistics Table 6A;quarterly frequency]

Portfolio Equity

0-1 dummy variable taking the value of 1 for a country which at time $i$ is among the one-third of the countries from our sample with the lowest/medium/highest $\left(X^{L O W} / X^{M E D} / X^{H I G H}\right)$ level of reported equity portfolio investments (assets + liabilities) to and from the rest of the world, and zero otherwise. For missing years 1994-1996 we use the 1997 data, and for 1998-2000 the 2001 data. [IMF, Coordinated Portfolio Investment Survey; annual frequency].

Portfolio Debt

$0-1$ dummy variable taking the value of 1 for a country which at time $i$ is among the one-third of the countries from our sample with the lowest/medium/highest $\left(X^{L O W} / X^{M E D} / X^{H I G H}\right)$ level of reported debt portfolio investments (assets + liabilities) to and from the rest of the world, and zero otherwise. For missing years 1994-1996 we use the 1997 data, and for 1998-2000 the 2001 data. [IMF, Coordinated Portfolio Investment Survey; annual frequency].

US equity

investment

$0-1$ dummy variable taking the value of 1 for a country which at time $i$ is among the one-third of the countries from our sample with the lowest/medium/highest $\left(X^{L O W} / X^{M E D} / X^{H I G H}\right)$ level of US equity portfolio investments as a percentage of their market capitalisation, and zero otherwise. [IMF, Coordinated Portfolio Investment Survey, World Bank; annual frequency].

XR Regime

Classification

Using the de facto classification of the exchange regime by Ilzetzki et al. (2010) we define a 0-1 dummy variable $X^{F L E X}$ taking the value of 1 if country $j$ at time $i$ has a flexible exchange rate regime (classification 3 or 4 ), and zero otherwise (classification 1 or 2). Analogously $X^{F I X E D}$ is a 0 1 dummy variable taking the value of 1 if country $j$ at time $i$ has a less flexible exchange rate regime (classification 1 or 2), and zero otherwise (classification 3 or 4 ).

XR Regime Volatility

0-1 dummy variable taking the value of 1 for a country which at time $i$ is among the one-third of the countries from our sample with the lowest/medium/highest $\left(X^{L O W} / X^{M E D} / X^{H I G H}\right)$ daily exchange rate changes standard deviation (against the US dollar), and zero otherwise. [WM/Reuters closing spot rates]

Lending from US

$0-1$ dummy variable taking the value of 1 for a country which at time $i$ is among the one-third of the countries from our sample with the highest amount of lending from the US banking system, and zero otherwise. [BIS consolidated banking statistics Table 9B; quarterly frequency] 